\title{
Phyllanthus emblica L. Branch Extract Ameliorates Testicular Damage in Valproic Acid-Induced Rats
}

\author{
El Extracto de la Rama de Phyllanthus emblica L. disminuye \\ el Daño Testicular Inducido por Ácido Valproico en Ratas
}

\begin{abstract}
Sitthichai Iamsaard",***; Supatcharee Arun",***; Jaturon Burawat ${ }^{*, * * * ; ~ W a n n i s a ~ S u k h o r u m ~}{ }^{*, * * * ;}$ Porntip Boonruangsri"; Malivalaya Namking*; Nongnut Uabundit*; Somsak Nualkaew** \& Bungorn Sripanidkulchai***
\end{abstract}

IAMSAARD, S.; ARUN, S.; BURAWAT, J.; SUKHORUM, W.; BOONRUANGSRI, P.; NAMKING, M.; UABUNDIT, N.; NUALKAEW, S. \& SRIPANIDKULCHAI, S. Phyllanthus emblica L. branch extract ameliorates testicular damage in valproic acidinduced rats. Int. J. Morphol., 33(3):1016-1022, 2015.

SUMMARY: Valproic acid (VPA), widely used in treating epileptic patients, can damage reproductive parameters causing male infertility. This study aimed to investigate protective effect of Phyllanthus emblica L. branch (PE) extract on rat testicular damage induced with VPA. Male rats were divided into 6 groups (control, VPA, $250 \mathrm{mg} / \mathrm{kgBW}$ PE only, and 50, 100, $250 \mathrm{mg} / \mathrm{kgBW}$ PE+VPA, respectively). Animals were pretreated with PE for 23 days and co-administered with VPA for 10 days before all reproductive parameters were determined. The results showed all doses of PE significantly protected the decrease testicular weight and testosterone level in VPA rats. PE significantly improved the decrease sperm concentration in VPA treated rats. Moreover, testicular histology of PE+VPA groups showed declining of testicular histopathologies as compared to VPA group. Therefore, it seems that PE branch extract can prevent testicular damages including male reproductive parameters in rats induced with VPA.

KEY WORDS: Valproic acid; Phyllanthus emblica L.; Testicular damage; Rats.

\section{INTRODUCTION}

Valproic acid (VPA) is an antiepileptic drug commonly used in the treatments of epileptic seizures including panic attack, anorexia nervosa, anxiety disorder, posttraumatic stress disorder, migraine, psychiatric conditions, and bipolar disorders (Löscher, 2002). As known mechanisms, VPA has the properties of sodium channel blockers, glutamate blocker, calcium current inhibitors, carbonic anhydrase inhibitors, and gamma-aminobutyric acid enhancers (Gelder et al., 2006). However, various side effects in the use of VPA have been also reported. VPA can cause many congenital malformations (Jentink et al., 2010; Witczak et al., 2010). It was also reported to significantly increase fibrosarcomas and adenocarcinomas of the uterus and cervix (Watkins et al., 1992). Moreover, VPA affects male reproductive system in both men and experimental animals. In the epileptic men treated with VPA, their testosterone levels and semen qualities have been significantly decreased (Herzog, 2008; Bauer et al., 2004; Isojärvi et al., 2004; Sveberg Roste et al., 2002) involving infertility (Bauer et al.). In animals, VPA significantly decreases FSH, LH, and testosterone hormones with testicular damages (Khan et al., 2011; Krogenase et al., 2008; Hamza \& Amin, 2007; Svenberg Roste et al.; Nishimura et al., 2000).

To prevent such side effects, many herbal medicines studies have been searching for alternative VPA treatments (Sakr et al., 2014; Hamza \& Amin). Phyllanthus emblica L. (PE) or Thai-Makham Pom is a famous plant recently used as traditional medicine for many properties. All part extracts of PE have been reported to have high phenolic contents and antioxidant capacities (Iamsaard et al., 2014a, 2014b; Liu et al., 2008; el-Mekkawy et al., 1995; Khanna \& Bansal, 1975; Srivastava \& Ranjan, 1967; Theresa et al., 1965; Basa \& Srinivasuku, 1987). PE extract has been reported to have

\footnotetext{
Department of Anatomy, Faculty of Medicine, Khon Kaen University, Khon Kaen, Thailand.

** Department of Pharmaceutical Sciences, Faculty of Pharmacy, Mahasarakham University, Mahasarakham, Thailand.

*** Center for Research and Development of Herbal Health Product, Faculty of Pharmaceutical Sciences, Khon Kaen, Thailand.

Grants: This project was financially supported by Center for Research and Development of Herbal Health Product, Faculty of Pharmaceutical Sciences (No. RD-HHP 05) and Invitation research grants, Faculty of Medicine, Khon Kaen University (No.I-57234).
} 
capacity in lipid peroxidation inhibition and anti-cancers (Krishnami \& Mirunalini, 20012; Lou et al., 2011; Zhong et al., 2011). Previously, PE extract has been demonstrated to prevent various tissues damages except the testis induced by chemicals or drugs (Pramayothin et al., 2006; Tasduq et al., 2005; Khandelwal et al., 2002; Dhuley \& Naik, 1997; Asmawi et al., 1993; Ahmed et al., 1998). This study attempted to demonstrate the protective effect of PE branch extract on reproductive organs damages in male rats induced with VPA.

\section{MATERIAL AND METHOD}

Plant collection and extraction. The branch extract of Phyllanthus emblica L. (PE), authenticated for its actual species by Prof. Dr. Pranom Chantaranothai and sample kept in the KKU Herbarium (\# Supatcharee Arun 01 [KKU]), was prepared in Dr. Sitthichai Iamsaard's laboratory and proven to have high phenolic contents and antioxidant capacities (Iamsaard et al., 2014b).

Animals and treatment regime. Three-months old, male Wistar rats (180-200 g), were purchased from the National Laboratory Animal Center, Salaya, Nakhon Pathom, Thailand. They were maintained on standard pellet diet and tap water ad libitum and were kept in polycarbonate cages with wood chip bedding under a $12 \mathrm{~h}$ light/dark cycle. Fortyeight rats were divided into six groups and each group $(\mathrm{n}=$ 8) was treated as shown in Table I. The study was approved by the Animal Ethics Committee of KKU, based on the Ethics of Animal Experimentation of the National Research Council of Thailand (ref. No. 0514.1.12.2/60).

Plasma testosterone assay. At the end of the experiment, all rats were euthanatized to expose the left ventricle of the heart. Blood was carefully punctured at the left ventricular chamber using $0.01 \mathrm{ml}$ of heparin to prevent blood clotting. Then, the blood was centrifuged $\left(5,000 \mathrm{r} / \mathrm{min}, 4^{\circ} \mathrm{C}, 10 \mathrm{~min}\right)$ to collect the plasma serum from blood cells. The plasma testosterone concentration was analyzed by the enzymatic immunoassay kits at the Radiology Unit, Srinagarind Hospital, Faculty of Medicine, KKU, Thailand.

Epididymal sperm concentration. The epididymal sperm concentration was performed as described by Iamsaard et al. (2014a). After animal sacrifice, sperm fluid was collected from both left epididymis and vas deferens. Sperm fluid was dipped and re-suspended in $1 \mathrm{ml}$ of phosphate buffer saline $\left(37^{\circ} \mathrm{C}, \mathrm{pH}\right.$ 7.4). Then, sperm suspension was centrifuged (3000 r/min, $37^{\circ} \mathrm{C}, 2 \mathrm{~min}$ ) to wash and separate the mature sperm pellet from its fluid. To analyze the epididymal sperm concentration, the sperm pellets were re-suspended with 1 $\mathrm{ml}$ PBS $\left(37^{\circ} \mathrm{C}, \mathrm{pH} 7.4\right)$ before dilution. The sperm dilusions (1:20 dilution) were counted for three times of each animal by using a Neubauer's counting chamber and calculated for its concentration.

Histopathological examinations of the testes and epididymes. At the end of the experimental periods, all rats of control and PE-VPA co-administration groups were weighed and sacrificed by cervical dislocation to carefully collect testis, and epididymis plus vas deferens. Immediately after sacrifice, these organs were cleaned of fats and weighed. Then, right side of the organs were fixed in $10 \%(\mathrm{v} / \mathrm{v})$ formalin in phosphate buffered saline (PBS) ( $\mathrm{pH} 7.4)$, dehydrated, embedded in paraffin, sectioned at $5 \mu \mathrm{m}$ thickness, and stained with hematoxylin-eosin to make the permanent glass slides (Iamsaard et al., 2014a). All sections of testes and cauda epididymis were examined under a Nikon light ECLIPSE E200 microscope equipped with a DXM1200 digital camera. Approximate average diameters of seminiferous tubules in four different axes (50 tubules per animal) (10x) were calculated by using ImageJ programe (Iamsaard et al., 2014a).

Statistical analysis. One-way analysis of variance (ANOVA) and t-test were performed to determine the significance of differences among data sets using Sigma Stat program (Version 3.1.1). All the quantitative data were expressed as Mean \pm Standard Deviation (SD).

Table I. Treatment on each group of rats.

\begin{tabular}{lll}
\hline \multirow{2}{*}{ Group } & \multicolumn{2}{c}{ Treatment } \\
\cline { 2 - 3 } & \multicolumn{1}{c}{ Days 1-23 (via a gastric tube) } & \multicolumn{1}{c}{ Days 24-33 (i. p. injection) } \\
\hline Positive control & Distilled wa ter, $1 \mathrm{ml}$ & Saline, $0.5 \mathrm{ml}$ \\
VPA (Negative control) & Distilled water, $1 \mathrm{ml}$ & VPA $(500 \mathrm{mg} / \mathrm{kg} \mathrm{BW}), 0.5 \mathrm{ml}$ \\
PE250 & PE branch extracts $(250 \mathrm{mg} / \mathrm{kg} \mathrm{BW}), 1 \mathrm{ml}$ & Saline, $0.5 \mathrm{ml}$ \\
PE50+VPA & PE branch extracts $(50 \mathrm{mg} / \mathrm{kg} \mathrm{BW}), 1 \mathrm{ml}$ & VPA $(500 \mathrm{mg} / \mathrm{kg} \mathrm{BW}), 0.5 \mathrm{ml}$ \\
PE100+VPA & PE branch ex tracts $(100 \mathrm{mg} / \mathrm{kg} \mathrm{BW}), 1 \mathrm{ml}$ & VPA $(500 \mathrm{mg} / \mathrm{kg} \mathrm{BW}), 0.5 \mathrm{ml}$ \\
PE250+VPA & PE branch extracts $(250 \mathrm{mg} / \mathrm{kg} \mathrm{BW}), 1 \mathrm{ml}$ & VPA $(500 \mathrm{mg} / \mathrm{kg} \mathrm{BW}), 0.5 \mathrm{ml}$
\end{tabular}

$\mathrm{BW}=$ body weight; $\mathrm{VPA}=$ valproic acid (saline-dissolved). The VPA group (Negative control) is designed based on Hamza \& Amin (2007). Days 1-23 are the preventive period and Days 24-33 are the VPA-induction period. 
IAMSAARD, S.; ARUN, S.; BURAWAT, J.; SUKHORUM, W.; BOONRUANGSRI, P.; NAMKING, M.; UABUNDIT, N.; NUALKAEW, S. \& SRIPANIDKULCHAI, S. Phyllanthus emblica L. branch extract ameliorates testicular damage in valproic acid-induced rats. Int. J. Morphol., 33(3):1016-1022, 2015.

\section{RESULTS}

After treatment for 33 consecutive days, the results showed that the testicular relative weights of rats treated with VPA were significantly decreased as compared to those of other groups $(\mathrm{P}<0.05$; Table II). In addition, the weights of epididymis plus vas deferens of VPA and among experimental groups were not significantly different from the control group $(\mathrm{P}<0.05$; Table II). VPA induced rats had significant reduction of serum testosterone levels as compared with the control. In contrast, PE branch extract $(250 \mathrm{mg} / \mathrm{kgBW})$ did not affect such levels, whereas 50, 100, and $250 \mathrm{mg} / \mathrm{kgBW}$ of PE branch extracts could prevent the decreased serum testosterone levels in VPA treated rats (Table II).

Sperm concentration of VPA induced group was significantly reduced while all PE-VPA groups including PE administration only were not significantly different as

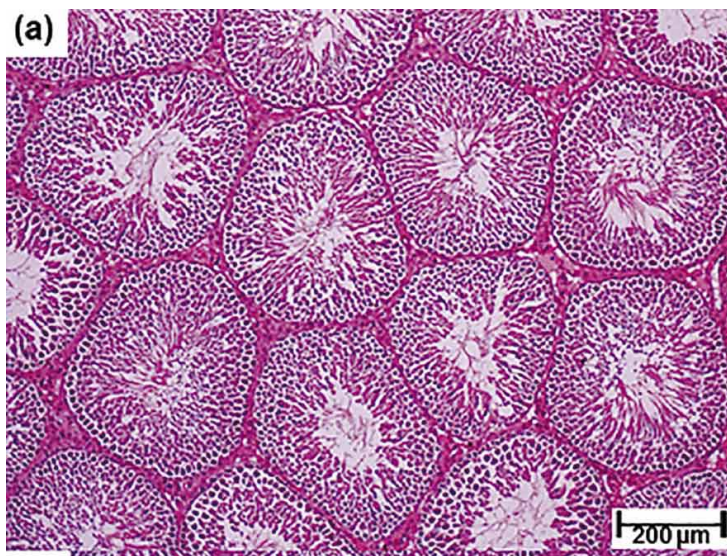

(c)

(b)

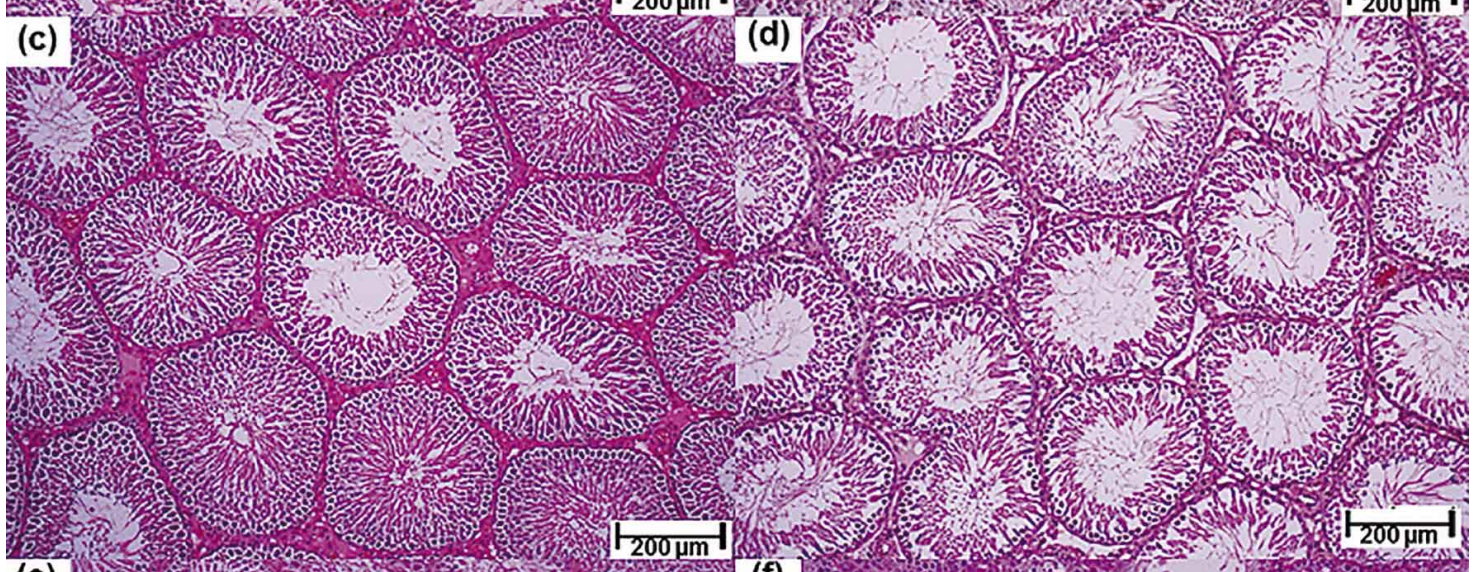

(e)

(f)

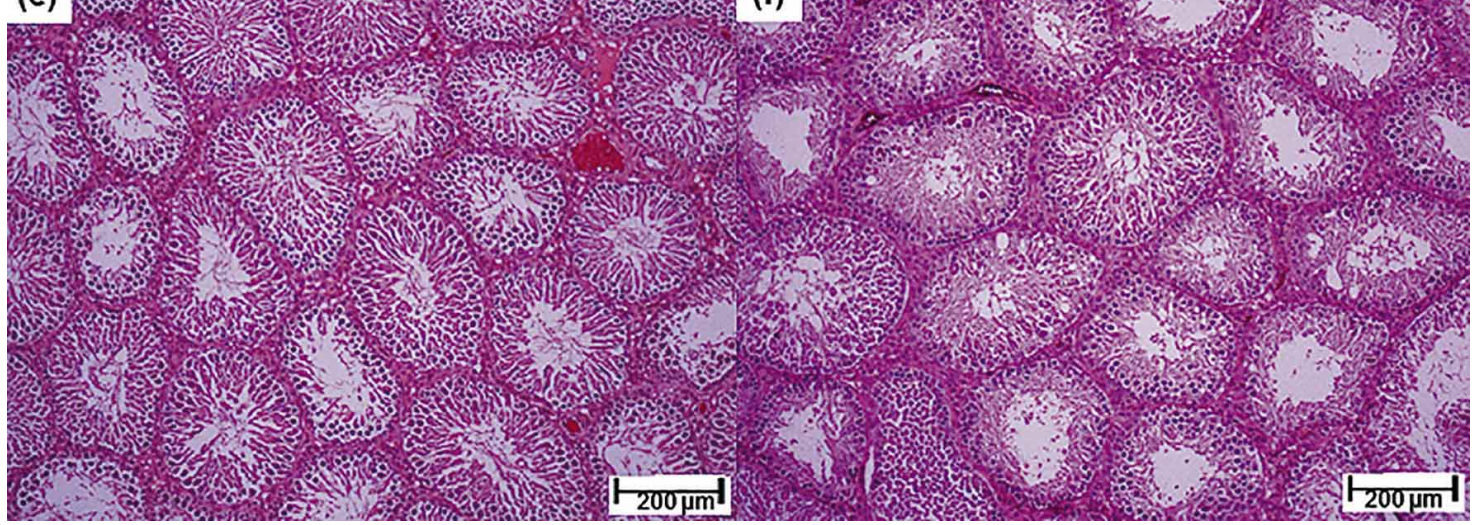

Fig. 1. Photographs showing testicular histology (H\&E) of rats from a representative sections (a) Control; (b) VPA-treated; (c) PE250; (d) PE50+VPA treated; (e) PE100+VPA treated; (d) PE250+VPA treated, respectively. 
IAMSAARD, S.; ARUN, S.; BURAWAT, J.; SUKHORUM, W.; BOONRUANGSRI, P.; NAMKING, M.; UABUNDIT, N.; NUALKAEW, S. \& SRIPANIDKULCHAI, S. Phyllanthus emblica L. branch extract ameliorates testicular damage in valproic acid-induced rats. Int. J. Morphol., 33(3):1016-1022, 2015.

compared with control group $(\mathrm{P}<0.05$; Table II). In addition, all doses of PE branch extracts could protect the reduced seminiferous tubular diameters in VPA treated rats $(\mathrm{P}<0.05$; Table II).

The preventive effects of PE branch extracts on testicular damage were evaluated by observing histopathological structures (Fig. 1). The result showed that rats pretreated with PE extract $50 \mathrm{mg} / \mathrm{kgBW}$ (Fig. 1d) showed improved histology as compared to the control and VPA groups. While, increase of interstitial space, atrophy of seminiferous tubules, and reduction of germinal epithelium could still be observed in the low dose of PE pretreatment. Interestingly, no histopathology in seminiferous tubule was observed only in rats of PE100+VPA, PE250+VPA, and PE250 only groups (Figs. 1c, 1e, and 1f).

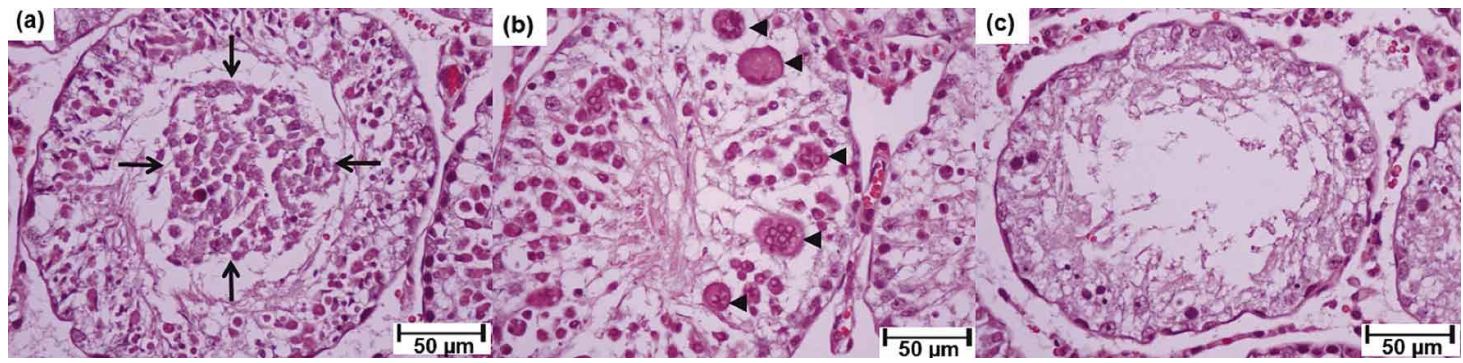

Fig. 2. Photographs showing histopathology (H\&E) of seminiferous tubules observed in VPA treated rats from representative sections (a) Sloughing germ cells (arrows); (b) Multinucleated giant cells (arrowhead); (c) Germ cell degeneration.

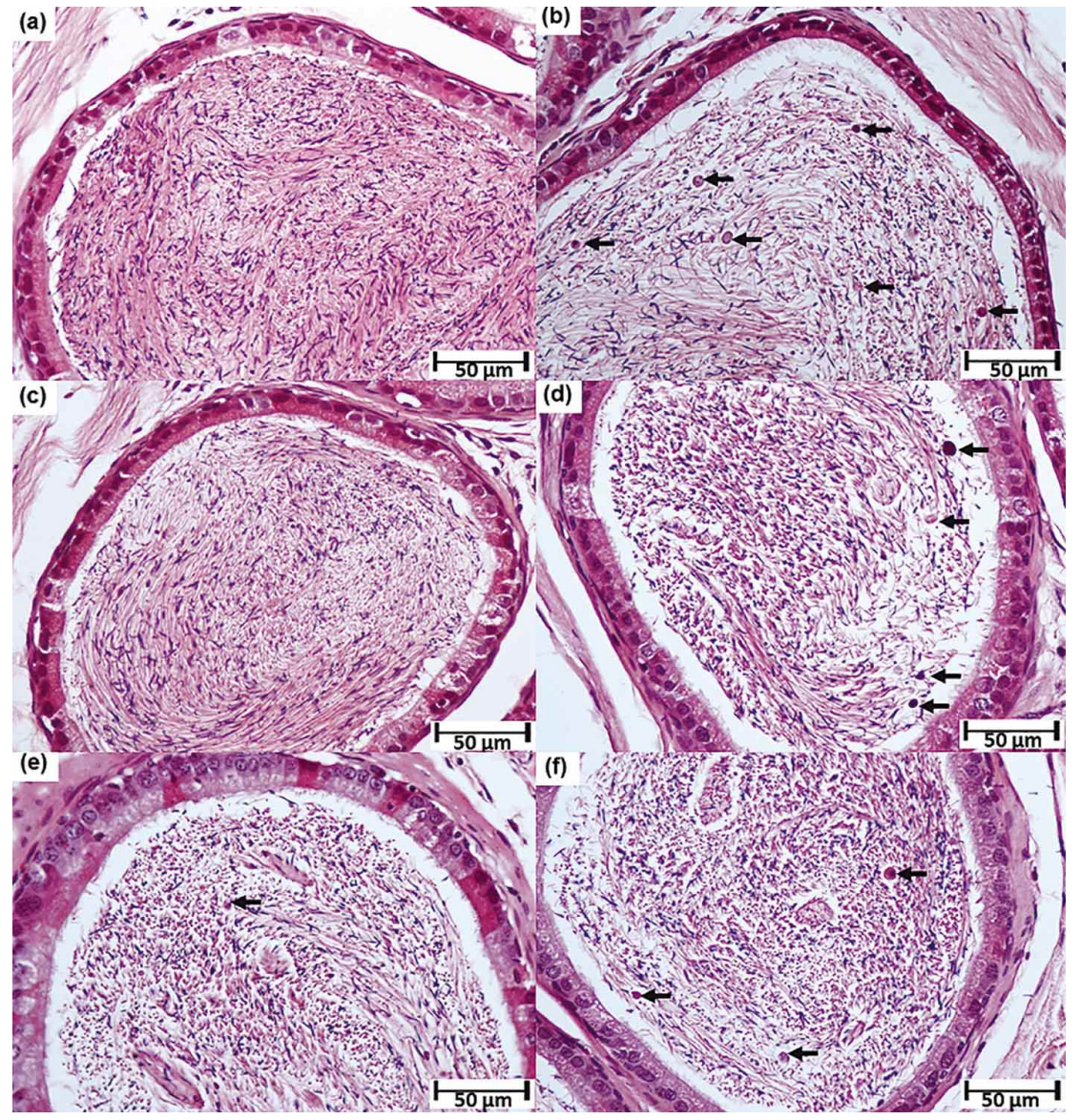

Fig. 3. Photographs showing rat epididymal histology (H\&E) from a representative sections (a) Control; (b) VPA; (c) PE250; (d) PE50+VPA; (e) PE100+VPA; (f) PE250+VPA, arrows represent round cells. Note: the round cells are abundant in the epididymal lumen of VPA group.
In observation of histopathology of seminiferous tubules structures, rats in VPA group only were found sloughing germ cells (Fig. 2a), multinucleated giant cells (Fig. 2b), and degenerated germ cells (Fig. 2c) in seminiferous tubules. However, these severities were not found in PE only group (PE 250 only) (Fig. 1c) and decreased in $\mathrm{PE}$ - treated groups (PE50+VPA group, PE100+VPA group, and PE250+VPA group, respectively) in dose dependents (Figs. 1d, 1e, and 1f).

\section{Effects of PE branch extracts on} epididymis histology. In all experimental groups, the epididymis histology observed in all groups was not different in epithelial lining arrangement (Fig. 3). In contrast, the epididymal lumen of VPA treated group was obviously found more round cells (Fig. 3b) as compared to those of control or PE group (Figs. 3a and 3c). In contrast, the round cells were much more less in 50, 100, and $250 \mathrm{mg} /$ kgBW PE+VPA groups, respectively (Figs. 3c and 3f). Moreover, the less sperm density was observed in VPA treated group as compared to other groups (Fig. 3). 
IAMSAARD, S.; ARUN, S.; BURAWAT, J.; SUKHORUM, W.; BOONRUANGSRI, P.; NAMKING, M.; UABUNDIT, N.; NUALKAEW, S. \& SRIPANIDKULCHAI, S. Phyllanthus emblica L. branch extract ameliorates testicular damage in valproic acid-induced rats. Int. J. Morphol., 33(3):1016-1022, 2015.

Table II Values of analyzed parameters on the reproductive system of control and experimental rats.

\begin{tabular}{lccccc}
\hline \multirow{2}{*}{ Group } & \multicolumn{2}{c}{ Relative weight $\mathbf{( g )}$} & $\begin{array}{c}\text { Testicular } \\
\text { diameter } \\
(\mu \mathrm{m})\end{array}$ & $\begin{array}{c}\text { Serum } \\
\text { testosterone } \\
\text { level }(\mathrm{ng} / \mathrm{ml})\end{array}$ & $\begin{array}{c}\text { Sperm } \\
\text { concentration } \\
\left(\mathrm{x} 10^{6} \text { cells/ml) }\right.\end{array}$ \\
\cline { 2 - 5 } Control & $0.50 \pm 0.03$ & $0.15 \pm 0.01$ & $202.42 \pm 7.36$ & $2.68 \pm 1.38$ & $34.50 \pm 3.96$ \\
VPA & $0.31 \pm 0.08^{*}$ & $0.14 \pm 0.01$ & $179.76 \pm 9.20^{*}$ & $0.07 \pm 0.05^{*}$ & $19.81 \pm 4.83^{*}$ \\
PE250 & $0.55 \pm 0.04$ & $0.16 \pm 0.01$ & $200.55 \pm 7.78$ & $2.24 \pm 0.94$ & $36.81 \pm 1.62$ \\
PE50+VPA & $0.43 \pm 0.02$ & $0.15 \pm 0.02$ & $191.95 \pm 5.20$ & $1.31 \pm 0.88^{*}$ & $30.96 \pm 1.93$ \\
PE100+VPA & $0.39 \pm 0.04$ & $0.14 \pm 0.03$ & $195.61 \pm 7.88$ & $1.23 \pm 0.74^{*}$ & $26.83 \pm 1.93$ \\
PE250+VPA & $0.39 \pm 0.05$ & $0.14 \pm 0.02$ & $190.11 \pm 6.27$ & $1.25 \pm 0.37^{*}$ & $27.30 \pm 2.12$ \\
\hline
\end{tabular}

* Significant differences $(\mathrm{P}<0.05)$ as compared with the control group. Data are expressed as mean $\pm \mathrm{SD}(\mathrm{n}=6)$.

\section{DISCUSSION}

This result revealed that $\mathrm{PE}$ branch extract significantly prevented testicular damage including decreased plasma testosterone levels, and sperm concentration. Previously, parts of PE extracts were reported to prevent the damages of liver (Pramyothin et al.; Tasduq et al.; Khandelwal et al.; Dhuley \& Naik; Ahmed et al.; Asmawi et al.), kidney (Khandelwal et al.) stomach (Bandyopadhyay et al., 2000; Ahmad et al.) and foot inflammation (Asmawi et al.). Moreover, it has been demonstrated that PE extract has anti-inflammatory and anticancer effects (Krishnaveni et al.; Lou et al.; Zhong et al.; Asmawi et al.). Besides protecting other tissues induced by drugs or chemicals, PE extract was shown for the first time in this study in prevention of testicular damage induced with VPA. This recent study also showed abnormality of VPAtreated epididymal histology with abundant round cells as compared to the control and PE-treated rats (Fig. 3). This evidence can explain the reason sperm concentration of VPA group are always significantly reduced (Table II). These sperm parameters including seminiferous tubule diameters and testicular histopathology were improved by PE extract treatments.

Some medicinal plants have been demonstrated to have preventive effects for testicular damages in VPA animal models (Sakr et al.; Hamza \& Amin). Similar to those results, PE extracts in this study might have abilities in decreasing of malondialdehyde (MDA) and increasing of catalase (CAT) and glutathione peroxidase (GSH-Px). These effects may include an improvement in sperm chromosomal aberrations, mitotic index, and DNA damages induced by VPA. Unfortunately, this study did not show those results; however, such biochemical analyses must be further investigated to elucidate the real mechanism underlying of $\mathrm{PE}$ protective effects. It can be clearly explained that PE extract used in this study is rich in phenolic contents and antioxidant capacities (Iamsaard et al., 2014b), which is si- milar to those of the fruit parts (She et al., 2013; Chalise et al.; Sawant et al., 2010). Indeed, PE extract did not affect any male reproductive organs including sperm parameters as compared to the control. This is because of its $50 \%$ lethal dose (LD50) is greater than 5,000 mg/kgBW (WHO, 2000) which it was used in this study at maximum dose of only $250 \mathrm{mg} / \mathrm{kg}$ BW. This recent study indicates that not only was the PE branch extract not harmful, but it could also prevent the weight loss of male reproductive organs in VPAinduced rats. In the same veins, previous studies have shown that plants containing antioxidant activity could prevent testicular damage induced by stress or chemicals (Iamsaard et al., 2014a; Hamsa \& Amin). Therefore, this study has provided the information of the safety use of PE extract with protective effect on testicular damage induced by VPA.

\section{ACKNOWLEDGMENTS}

We would like to gratefully thank the Center for Research and Development of Herbal Health Product, Faculty of Pharmaceutical Sciences (No. RD-HHP 05) and Invitation research grants from Faculty of Medicine, Khon Kaen University for financial support this project (No.I57234).

IAMSAARD, S.; ARUN, S.; BURAWAT, J.; SUKHORUM, W.; BOONRUANGSRI, P.; NAMKING, M.; UABUNDIT, N.; NUALKAEW, S. \& SRIPANIDKULCHAI, S. El extracto de la rama de Phyllanthus emblica L. disminuye el daño testicular inducido por ácido valproico en ratas. Int. J. Morphol., 33(3):1016$1022,2015$.

RESUMEN: El ácido valproico (AVP) es utilizado frecuentemente en el tratamiento de pacientes epilépticos y puede dañar los parámetros reproductivos que causan la infertilidad mas- 
culina. Este estudio tuvo como objetivo investigar el efecto protector de la rama Phyllanthus emblica L. (PE) sobre el daño testicular de ratas inducidas con AVP. Ratas machos fueron divididas en 6 grupos (control, AVP, PE $250 \mathrm{mg} / \mathrm{kg}$ peso corporal, APV+ PE 50, 100, $250 \mathrm{mg} / \mathrm{kg}$ peso corporal, respectivamente). Los animales fueron pretratados con PE durante 23 días y se administró AVP durante 10 días antes de medir todos los parámetros reproductivos. Los resultados mostraron que todas las dosis de PE protegen significativamente el peso y los niveles reducidos de testosterona testicular en ratas con AVP. El extracto de PE mejoró significativamente la concentración de espermatozoides en ratas tratadas con AVP. Por otra parte, la histología testicular de los grupos PE+AVP mostró disminución de la histopatología testicular en comparación con el grupo tratado sólo con AVP. Por lo tanto, parece que el extracto de la rama PE puede prevenir daños testiculares incluyendo los parámetros reproductores masculinos en ratas inducidas con AVP.

PALABRAS CLAVE: Ácido valpróico; Phyllanthus emblica L.; Daño testicular; Ratas.

\section{REFERENCES}

Ahmed, K. D.; Gilani, S. N.; Akhta, A. H. \& Khan, L. Antiulcerogenic evaluation of aqueous extracts of cichorium intybus and Phyllanthus emblica in normal and aspirin-treated rats. Pak. J. Sci. Ind. Res., 41(2):92-6, 1998.

Asmawi, M. Z.; Kankaanranta, H.; Moilanen, E. \& Vapaatalo, H. Antiinflammatory activities of Emblica officinalis Gaertn leaf extracts. J. Pharm. Pharmacol., 45(6):581-4, 1993.

Bandyopadhyay, S. K.; Pakrashi, S. C. \& Pakrashi, A. The role of antioxidant activity of Phyllanthus emblica fruits on prevention from indomethacin induced gastric ulcer. J. Ethnopharmacol., 70(2):171-6, 2000.

Basa, S. C. \& Shrinivasulu, C. Constituents of leaves of Phyllanthus emblica Linn. Indian J. Nat. Prod., 3(1):13-4, 1987.

Bauer, J.; Blumenthal, S.; Reuber, M. \& Stoffel-Wangner, B. Epilepsy syndrome, focus location, and treatment choice affect testicular function in men with epilepsy. Neurology, 62(2):243-6, 2004.

Chalise, J. P.; Acharya, K.; Gurung, N.; Bhusal, R. P.; Gurung R.; Skalko-Basnet, N. \& Basnet, P. Antioxidant activity and polyphenol content in edible wild fruits from Nepal. Int. J. Food Sci. Nutr., 61(4):425-32, 2010.

Dhuley, N. J. \& Naik, S. R. Protective effect of Rhinax, a herbal formulation, against $\mathrm{CCl} 4$-induced liver injury and survival in rats. J. Ethnopharmacol., 56(2):159-64, 1997.

el-Mekkawy, S.; Meselhy, M. R.; Kusumoto, I. T.; Kadota, S.; Hattori, M. \& Namba, T. Inhibitory effects of Egyptian folk medicines on human immunodeficiency virus (HIV) reverse transcriptase. Chem. Pharm. Bull. (Tokyo), 43(4):641-8, 1995.
Gelder, M.; Mayou, R. \& Geddes, J. Psychiatry. 3rd ed. Oxford, Oxford University Press, 2006.

Hamza, A. A. \& Amin, A. Apium graveolens modulates sodium valproate-induced reproductive toxicity in rats. J. Exp. Zool. A Ecol. Genet. Physiol., 307(4):199-206, 2007.

Herzog, A. G. Disorders of reproduction in patients with epilepsy: primary neurological mechanisms. Seizure, 17(2):101-10, 2008.

Iamsaard, S.; Burawat, J.; Kanla, P.; Arun, S.; Sukhorum, W.; Sripanidkulchai, B.; Uabundit, N.; Wattathorn, J.; Hipkaeo, W.; Fongmoon, D. \& Kondo, H. Antioxidant activity and protective effect of Clitoria ternatea flower extract on testicular damage induced by ketoconazole in rats. J. Zhejiang Univ. Sci. B, 15(6):548-55, 2014a.

Iamsaard, S.; Arun, S.; Burawat, J.; Sukhorum, W.; Wattanathorn, J.; Nualkaew, S. \& Sripanidkulchai, B. Phenolic contents and antioxidant capacities of Thai-Makham Pom (Phyllanthus emblica L.) aqueous extracts. J. Zhejiang Univ. Sci. B., 15(4):405-8, 2014 b.

Isojärvi, J. I.; Löfgren, E.; Juntunen, K. S.; Pakarinen, A. J.; Päivänsalo, M.; Rautakorpi, I. \& Tuomivaara, L. Effect of epilepsy and antiepileptic drugs on male reproductive health. Neurology, 62(2):247-53, 2004.

Jentink, J.; Loane, M. A.; Dolk, H.; Barisic, I.; Garne, E.; Morris, J. K.; de Jong-van den Berg, L. T. \& EUROCAT Antiepileptic Study Working Group. Valproic acid monotherapy in pregnancy and major congenital malformations. N. Engl. J. Med., 362(23):218593, 2010.

Khan, S.; Ahmad, T.; Parekh, C. V.; Trivedi, P. P.; Kushwaha, S. \& Jena, G. Investigation on sodium valproate induced germ cell damage, oxidative stress and genotoxicity in male Swiss mice. Reprod. Toxicol., 32(4):385-94, 2011.

Khandelwal, S.; Shukla, L. J. \& Shanker, R. Modulation of acute cadmium toxicity by Emblica officinalis fruit in rat. Indian J. Exp. Biol., 40(5):564-70, 2002.

Khanna, P. \& Bansal, R. Phyllantidine and phyllantine from Emblica officinalis Gaertn leaves, fruits, and in vitro tissue cultures. Indian J. Exp. Biol., 13(1):82-3, 1975.

Krishnaveni, M. \& Mirunalini, S. Chemopreventive efficacy of Phyllanthus emblica L. (amla) fruit extract on 7,12dimethylbenz(a)anthracene induced oral carcinogenesis--a doseresponse study. Environ. Toxicol. Pharmacol., 34(3):801-10, 2012.

Krogenaes, A. K.; Taubøll, E.; Stien, A.; Oskam, I. C.; Lyche, J. L.; Dahl, E.; Thomassen, R. F.; Sweeney, T. \& Ropstad, E. Valproate affects reproductive endocrine function, testis diameter and some semen variables in non-epileptic adolescent goat bucks. Theriogenology,70(1):15-26, 2008.

Löscher, W. Basic pharmacology of valproate: a review after 35 years of clinical use for the treatment of epilepsy. C. N. S. Drugs, 16(10):669-94, 2002. 
IAMSAARD, S.; ARUN, S.; BURAWAT, J.; SUKHORUM, W.; BOONRUANGSRI, P.; NAMKING, M.; UABUNDIT, N.; NUALKAEW, S. \& SRIPANIDKULCHAI, S. Phyllanthus emblica L. branch extract ameliorates testicular damage in valproic acid-induced rats. Int. J. Morphol., 33(3):1016-1022, 2015.

Liu, X.; Cui, C.; Zhao, M.; Wang, J.; Luo, W.; Yang, B. \& Jiang, Y. Identification of phenolics in the fruit of emblica (Phyllanthus emblica L.) and their antioxidant activities. Food Chem., 109(4):909-15, 2008.

Luo, W.; Zhao, M.; Yang, B; Ren, J.; Shen, G. \& Rao, G. Antioxidant and antiproliferative capacities of phenolics purified from Phyllanthus emblica L. fruit. Food Chem., 126(1):277-82, 2011.

Nishimura, T.; Sakai, M. \& Yonezawa, H. Effects of valproic acid on fertility and reproductive organs in male rats. J. Toxicol. Sci., 25(2):85-93, 2000.

Pramyothin, P.; Samosorn, P.; Poungshompoo, S. \& Chaichantipyuth, C. The protective effects of Phyllanthus emblica Linn. extract on ethanol induced rat hepatic injury. J. Ethnopharmacol., 107(3):3614, 2006.

Sakr, S. A.; Zowail, M. E. \& Marzouk, A. M. Effect of saffron (Crocus sativus L.) on sodium valporate induced cytogenetic and testicular alterations in albino rats. Anat. Cell Biol., 47(3):171-9, 2014.

Sawant, L.; Pandita, N. \& Prabhakar, B. Determination of gallic acid in Phyllanthus emblica Linn. dried fruit powder by HPTLC. J. Pharm. Bioallied Sci., 2(2):105-8, 2010.

She, G.; Cheng, R.; Sha, L.; Xu, Y.; Shi, R.; Zhang, L. \& Guo, Y. A novel phenolic compound from Phyllanthus emblica. Nat. Prod. Commun., 8(4):461-2, 2013.

Srivastava, S. K. \& Ranjan, S. Physiological studies on plant tannins III. Variation of tannin compounds in the developing fruits of Emblica officinalis (GAERTN). Flora Allg. Bot. Zeit (Jena), 158:133-41, 1967.

Sveberg Roste, L.; Taubøll, E.; Isojärvi, J. I.; Pakarinen, A. J.; Huhtaniemi, I. T.; Knip, M. \& Gjerstad, L. Effects of chronic valproate treatment on reproductive endocrine hormones in female and male Wistar rats. Reprod. Toxicol., 16(6):767-73, 2002.

Tasduq, S. A.; Mondhe, D. M.; Gupta, D. K.; Baleshwar, M. \& Johri, R. K. Reversal of fibrogenic events in liver by Emblica officinalis (fruit), an Indian natural drug. Biol. Pharm. Bull., 28(7):1304-6, 2005.

Theresa, Y. M.; Sastry, K. N. S. \& Nayudamma, Y. Studies on biosynthesis of tannins in indigenous plants XII. Occurence of different polyphenolics in amla (Phyllanthus emblica Linn). Leather Sci., 12:327-8, 1965.

Watkins, J. R.; Gough, A. W.; McGuire, E. J.; Goldenthal, E. \& de la Iglesia, F. A. Calcium valproate-induced uterine adenocarcinomas in Wistar rats. Toxicology, 71(1-2):35-47, 1992.

Witczak, M.; Kociszewska, I.; Wilczyn'ski, J.; Lopaczyn'ska, D. \& Ferenc, T. Evaluation of chromosome aberrations, sister chromatid exchange and micronuclei in cultured cord-blood lymphocytes of newborns of women treated for epilepsy during pregnancy. Mutat. Res., 701(2):111-7, 2010.
World Health Organization (WHO). General Guidelines for Methodologies on Research and Evaluation of Traditional Medicine. Geneva, World Health Organization (WHO), 2000.

Zhong, Z. G.; Wu, D. P.; Huang, J. L.; Liang, H.; Pan, Z. H.; Zhang, W. Y. \& Lu, H. M. Progallin A isolated from the acetic ether part of the leaves of Phyllanthus emblica L. induces apoptosis of human hepatocellular carcinoma BEL-7404 cells by up-regulation of Bax expression and down-regulation of Bcl-2 expression. J. Ethnopharmacol., 133(2):765-72, 2011.

\section{Correspondence to: \\ Dr. Sitthichai lamsaard \\ Department of Anatomy \\ Faculty of Medicine \\ Khon Kaen University \\ 123 Mitraparp Road \\ Amphoe Muang \\ Khon Kaen 40002 \\ THAILAND}

Tel: +66-4336-3212

Fax: +66-4336-3212

Email: sittia@kku.ac.th

Received: 24-12-2014

Accepted: 13-07-2015 